\title{
Effect of mother-in-law's tongue leaves (Sansevieria trifasciata) extract's solvent polarity on anti-diabetic activity through in vitro a-glucosidase enzyme inhibition test
}

\author{
Mauhibah Yumna ${ }^{1}$, Angelina ${ }^{1}$, Abdullah $^{1}$, Rita Arbianti ${ }^{1{ }^{*}}$, Tania Surya Utami $^{1}$, and Heri Hermansyah ${ }^{1}$ \\ ${ }^{1}$ Department of Chemical Engineering, Faculty of Engineering, Universitas Indonesia, Depok 16424, Indonesia
}

\begin{abstract}
Diabetes Mellitus (DM) is a metabolic disease caused by elevated blood glucose levels above normal values (hyperglycemia). Natural ingredients that contain hypoglycemic substances, can become an alternative treatment of DM, i.e. mother-in-law's tongue leaves (Sansevieria trifasciata), which is known to contain flavonoids, glycosides, alkaloid, and steroids that have anti-diabetic activity. The goal of this research is to obtain mother-in-law's tongue leaves crude extract which has the highest anti-diabetic activity as an $\alpha$ glucosidase inhibitor. The result showed that from all solvents used, which is aquadest, $70 \%$ ethanol, and $70 \%$ ethyl acetate, extracted with $70 \%$ ethanol has the highest yield value, which is $12.69 \%$. The percentage of inhibition $\alpha$-glucosidase was $90.72 \%$ at the inhibitor concentration of 4708.71 . This shows that the extract with $70 \%$ ethanol has the required bioactive compound content to act as the $\alpha$-glucosidase enzyme inhibitor. Based on the identification of compounds found in the sample mother-in-law's tongue leaves extract with $70 \%$ ethanol using Gas Chromatography and Mass Spectrometry (GC-MS), compounds that have antidiabetic activity is steroids, alkaloids, terpenoids, tocopherol, and flavonoid.
\end{abstract}

\section{Introduction}

People have experienced degenerative metabolic diseases, one of many diseases is diabetes mellitus (DM). DM is a metabolic disease caused by elevated blood glucose levels above normal values (hyperglycemia). The disease is caused by impaired glucose metabolism due to insulin deficiency both in absolute and relative. DM is the most common metabolic syndrome worldwide with an incidence rate of $1-8 \%$. According to $\mathrm{WHO}{ }^{[1]}$, Indonesia ranks $4^{\text {th }}$ largest in the world.

Oral application of hypoglycemic substances from synthetic materials can cause excessive side effects. One of the natural ingredients that can lower blood glucose levels is the leaves of mother-in-law's tongue (Sansevieria trifasciata). The decoction of the mother-inlaw's tongue leaves is commonly used by people from Sabah, Malaysia for the treatment of DM disease ${ }^{[2]}$. The medical efficacy of the leaves of the mother-in-law's tongue is related, among others, to the treatment of DM, earache, pharyngitis, skin itching, and urinary diseases as an analgesic and antipyretic ${ }^{[3][4][5][6]}$.

The hypoglycemic effect of the plant bioactive component can restore pancreatic $\beta$ cell function, thereby increasing insulin secretion, inhibiting glucose absorption in the intestine and inhibiting the action of the $\alpha$ glucosidase enzyme. The leaves of the mother-in-law's tongue extracted with ethanol or aquadest solvent contain various phytochemical compounds commonly grouped in the form of alkaloids, flavonoids, saponins, glycosides, terpenoids, tannins, proteins, and carbohydrates [6]. Several studies that have proven the biological effects of the ethanol extract of the leaves of the mother-in-law's tongue are the analgesic and antipyretic effects ${ }^{[6]}$, antibacterial ${ }^{[7]}$ and antioxidants ${ }^{[8]}$. In addition, the leaves of mother-in-law's tongue also have an anti-diabetic effect with in vivo test ${ }^{[9]}$. The soluble active compounds in ethyl acetate are active compounds which can be well extracted. One of the compounds contained in the ethyl acetate fraction is flavanol ${ }^{[10]}$.

From the description above it is known that differences in the nature of polarity of the solvent can affect the number of extractive substances dissolved in the sample extract tested ${ }^{[11]}$. Polar solvents commonly used for flavonoid extraction are methanol, acetone, ethanol, aquadest, ethyl acetate and isopropanol ${ }^{[12]}$. Therefore, the solvents to be used in this study were aquadest, $70 \%$ ethanol, and $70 \%$ ethyl acetate to see how the polarity ability of each type of solvent was tested. In this research, the method to be performed is by testing the activity of the $\alpha$-glucosidase enzyme that plays a role in the process of glucose in vitro metabolism on the leaves of the motherin-law's tongue which has been extracted by sonication extraction method. The results of the proposed research are expected to be used as one of the basic in the manufacture of DM drugs with the basic ingredients of mother-in-law's tongue leaves extract.

\footnotetext{
* Corresponding author: arbianti@che.ui.ac.id
} 


\section{Materials and Methods}

\subsection{Materials}

\subsubsection{Substances}

The dried leaves of Sansevieria trifasciata were obtained from Bogor, Indonesia. Aquadest, ethanol, and ethyl acetate were obtained from bioprocess engineering laboratory. The $\alpha$-glucosidase enzymes (from Saccharomyces cerevisiae type I) and 4-nitrophenyl $\alpha$-Dglucopyranoside substrate were purchased from SigmaAldrich (Singapore). The acarbose as a comparison solution sample positive control.

\subsubsection{Instruments}

Ultrasonic cleaner bath (sonicator), ELISA microplate reader (410 nm), Gas Chromatography and Mass Spectrometry (GC-MS) Agilent Technologies 6890N Network GC system for gas chromatography.

\subsection{Methodology}

\subsubsection{Preparation of Mother-in-Law's Tongue Leaves Powder}

Sorting, washing, and draining the sample of the motherin-law's tongue leaves. Cut the leaf sample and weigh the wet weight of $1000 \mathrm{~g}$. Next, dry the leaves by using the oven at $60^{\circ} \mathrm{C}$ for $8 \mathrm{~h}$ /day. Smooth the leaves with a blender and sift the leaves with a sieve analyzer to obtain leaf diameter $\pm 0.15-0.18 \mathrm{~mm}$.

\subsubsection{Extraction of Mother-in-Law's Tongue Leaves}

Mother-in-law's tongue leaves powder was dissolved in variation type of solvents, i.e. aquadest, $70 \%$ ethanol, and $70 \%$ ethyl acetate by $1: 10$ ratio of mass and solvent $(\mathrm{m} / \mathrm{v})$. Then, extraction using sonicator for 60 minutes at a frequency of $53 \mathrm{kHz}$ and $27^{\circ} \mathrm{C}$, continued by solvent evaporating using a vacuum rotary evaporator.

\subsubsection{In vitro $\alpha$-Glucosidase Enzyme Inhibition Test}

The enzyme inhibition activities for $\alpha$-glucosidase were evaluated according to the method previously reported by Sancheti et al. ${ }^{[13]}$ with minor modifications. The reaction mixture consisted $50 \mu \mathrm{L}$ of $0.1 \mathrm{M}$ phosphate buffer $(\mathrm{pH}$ 7.0), $25 \mu \mathrm{L}$ of $0.5 \mu \mathrm{mM}$ 4-nitrophenyl $\alpha$-Dglucopyranoside (dissolved in $0.1 \mathrm{M}$ phosphate buffer, $\mathrm{pH}$ 7.0), $10 \mu \mathrm{L}$ of test sample (main concentration for each extract: $1000 \mu \mathrm{g} \mathrm{mL}^{-1}$ ) and $25 \mu \mathrm{L}$ of $\alpha$-glucosidase solution (a stock solution of $1 \mathrm{mg} \mathrm{mL}^{-1}$ in $0.1 \mathrm{M}$ phosphate buffer, $\mathrm{pH} 7.0$ was diluted 0.04 Units $\mathrm{mL}^{-1}$ with the same buffer, $\mathrm{pH} 7.0$ just before assay). This reaction mixture was then incubated at $37^{\circ} \mathrm{C}$ for $30 \mathrm{~min}$. Then, the reaction was terminated by the addition of $100 \mu \mathrm{L}$ of $0.2 \mathrm{M}$ sodium carbonate solution.
The enzymatic hydrolysis of a substrate was monitored by the amount of $\mathrm{p}$-nitrophenol released in the reaction mixture at $410 \mathrm{~nm}$ using ELISA microplate reader. All experiments were carried out in triplicates.

\subsubsection{Quantitive test using Gas Chromatography- Mass Spectrometry (GC-MS)}

The sample was taken $6 \mu \mathrm{L}$ and insert the sample by injecting into the GC-MS inlet. Conducting quantitive analysis of component and separation of a compound on GC by capillary column with diameter $0.25 \mathrm{~mm}$ and length $60 \mathrm{~m}$ with initial temperature $40^{\circ} \mathrm{C}$ (temperature rise in $15^{\circ} \mathrm{C} / \mathrm{min}$ until temperature reaches $290^{\circ} \mathrm{C}$ and the end time of $10 \mathrm{~min}$ ). The identification of compounds is done by matching the mass spectral data with the database present in the WILEY $9^{\text {th }}$ library.

\section{Result and Discussion}

\subsection{Yield percentage value of Mother-in-Law's Tongue extract}

Extraction by sonication produces yield from all of the solvent used. Extract with $70 \%$ ethanol had the highest yield value, $12.69 \%$, followed by extract aquadest and extract $70 \%$ ethyl acetate with yield $10.37 \%$ and $6.65 \%$. Based on the result, the highest percentage of extract yield was obtained from mother-in-law's tongue leaves extract with $70 \%$ ethanol. This showed that the leaves of motherin-law's tongue have the same characteristics of polarity compounds as ethanol solvents.

\subsection{In vitro $\alpha$-Glucosidase Enzyme Inhibition Test}

Inhibition of the $\alpha$-glucosidase enzyme was performed to determine the presence or absence of anti-diabetic activity in the leaves of mother-in-law's tongue extracts. Enzyme $\alpha$-glucosidase is an enzyme that plays a role in the formation of glucose in the human small intestine through carbohydrate hydrolysis. Inhibition of the action of this enzyme can be done to prevent the drastic increase of glucose levels in the body of type II DM through delaying the process of breaking carbohydrates so that it can delay the absorption of glucose by the intestine into the blood. Based on research conducted by Yulianti et al. ${ }^{[14]}$, a preliminary test has been conducted at a concentration of $125 \mathrm{ppm}$ in order to find the optimum condition for the inhibition test. This mother-in-law's tongue leaves inhibition test using concentration at $125 \mathrm{ppm}$ results shown in Table 1 below.

Table 1. \% Inhibition at $125 \mathrm{ppm}$

\begin{tabular}{|c|c|c|}
\hline Sample & $\begin{array}{c}\text { Concentration } \\
(\mathrm{ppm})\end{array}$ & $\begin{array}{c}\text { Inhibition } \\
(\%)\end{array}$ \\
\hline Aquades Extract & 125 & 5.427 \\
\hline $70 \%$ Ethanol Extract & 125 & 5.561 \\
\hline $70 \%$ Ethyl Acetate Extract & 125 & 4.121 \\
\hline
\end{tabular}


Based on the data showed in Table 1, the percentage value of inhibition showed that $\alpha$-glucosidase enzyme in the sample extract at concentration $125 \mathrm{ppm}$ was already active because it showed the result. However, the control positive (acarbose) has a higher percentage value of inhibition at a concentration of $10 \mathrm{ppm}$ with $93.52 \%$. This indicates that the sample extract should be increased the concentration range to obtain concentration value when the percentage of inhibition reaches $50 \%\left(\mathrm{IC}_{50}\right)$. The purpose of using $\mathrm{IC}_{50}$ parameter is to know the activity of sample extract at how many concentration when the percentage value of inhibition reaches $50 \%$.

Since the trial data didn't show inhibition percentage more than $50 \%$, then the sample concentration should be increased. The increased concentration showed on the graph in Fig. 1.

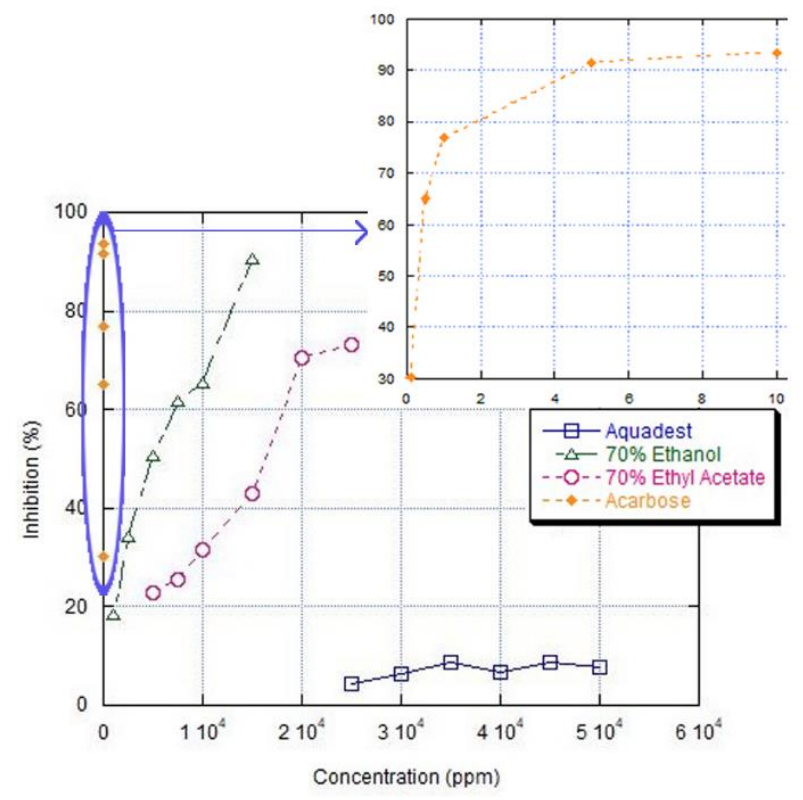

Fig. 1. Comparison of All Sample

The graph in Fig 1 shows the relationship between the percentage of inhibition and the concentration of the sample extract. The orange line in Fig 1 shows that acarbose as a positive control has a higher activity than the extract. This is due to a patented diabetes-specific acarbose that contains 100 pounds of pure acarbose, while the leaves of the mother-in-law's tongue extract contain a mixture of various bioactive and inactive compounds as anti-diabetes.

The correlation between the concentration range of each sample shows that the sample extract will reach its active point of inhibition percentage when the concentration is increased. This is due to the sample extract using different solvents, which have different polarity index values and dielectric constants. 70\% ethanol solvent has a good polarity profile and having a fairly active concentration range when compared with $70 \%$ ethyl acetate and aquadest. This indicates that the bioactive compounds in the extract with $70 \%$ ethanol are more bounded due to its better polarity properties than the $70 \%$ ethyl acetate and aquadest.

The percentage inhibition of acarbose was $93.52 \%$ with a concentration of $10 \mathrm{ppm}$, while the percentage value of $70 \%$ ethanol extract inhibition was $90.72 \%$ at $15000 \mathrm{ppm}$ concentration. The test results on Table 2 also showed that inhibitory activity of the $\alpha$-glucosidase enzyme by acarbose drug, extract of $70 \%$ ethanol, and extract of $70 \%$ ethyl acetate has an $\mathrm{IC}_{50}$ value of $0.25 \mathrm{ppm}$, $4708.71 \mathrm{ppm}$, and $15161.72 \mathrm{ppm}$.

Table 2. $\mathrm{IC}_{50}$ Value of All Sample

\begin{tabular}{|c|c|}
\hline Sample & $\mathrm{IC}_{50}(\mathrm{ppm})$ \\
\hline Aquades Extract & $>50000$ \\
\hline $\begin{array}{c}70 \% \text { Ethanol } \\
\text { Extract }\end{array}$ & 4708.71 \\
\hline $\begin{array}{c}70 \% \text { Ethyl Acetate } \\
\text { Extract }\end{array}$ & 15161.72 \\
\hline Acarbose & 0.25 \\
\hline
\end{tabular}

$\mathrm{IC}_{50}$ value of aquadest extract can't be calculated, because of the inhibition activity is less than $50 \%$ although the concentration has been extended to 25000-50000 ppm range. The data showed that among the aquadest extract, $70 \%$ ethanol, and $70 \%$ ethyl acetate, $70 \%$ ethanol extract had the best anti-diabetic activity because it had the highest inhibition percentage value, $90.72 \%$ and the lowest $\mathrm{IC}_{50}$ was $4708.71 \mathrm{ppm}$. However, when compared with the positive control (acarbose), 70\% ethanol extract is still classified as weak (inactive) in inhibiting antidiabetic activity. It also indicates that the sample concentration is influenced by the solvency polarity index used in each extract.

\subsection{Quantitive test using Gas Chromatography and Mass Spectrometry (GC-MS)}

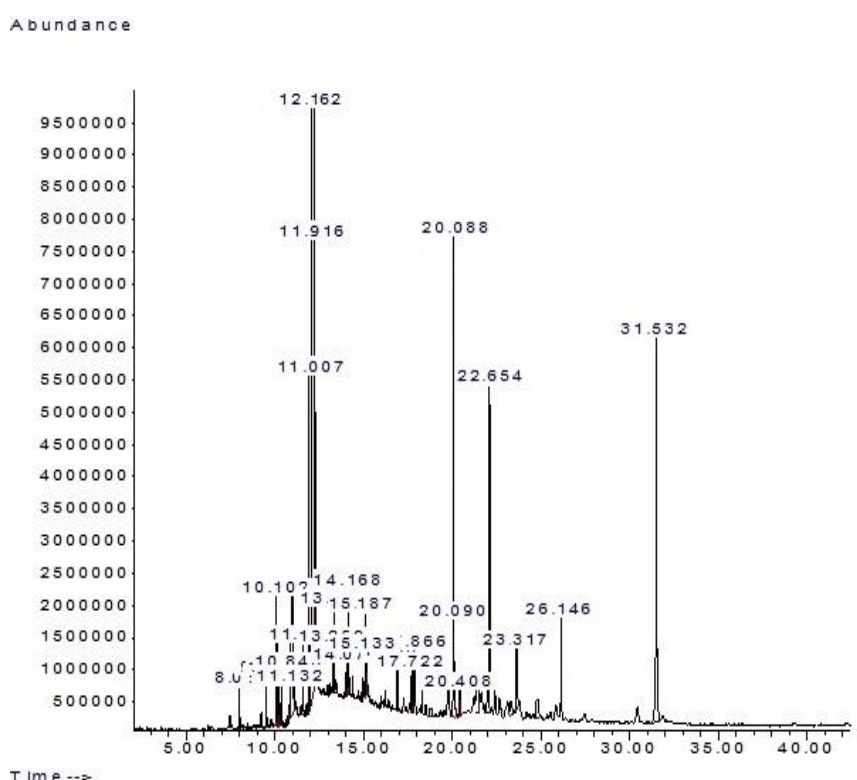

Fig. 2. GC-MS chromatogram of crude extract from Mother-inLaw's Tongue leaves

Based on the identification of compounds found in the sample mother-in-law's tongue leaves extract with $70 \%$ ethanol using GC-MS, compounds that have anti-diabetic activity is steroids, alkaloids, terpenoids, tocopherol, and 
flavonoid. These compounds are found in the retention time of $11.007,11.916,12.162,20.088,22.654$, and 31.532 min respectively (see Fig. 2).

Matthew et al. ${ }^{[15]}$ explain that natural compounds with anti-diabetic activity in descending frequency of occurrence include, complex carbon hydrates, alkaloids, glycopeptides, terpenoids, peptides, amines, steroids, flavonoids, lipids, coumarins, sulfur compounds and inorganic ions. The results of the GC-MS test showed in Table 3 below.

Table 3. The bioactive compound from GC-MS test

\begin{tabular}{|c|c|c|c|}
\hline No & $\begin{array}{c}\text { Compounds } \\
\text { Name }\end{array}$ & $\begin{array}{c}\text { Concentration } \\
(\%)\end{array}$ & Bioactivity $^{(\%)}$ \\
\hline 1 & Linoleic Acid & 20 & Antioxidants $^{[16]}$ \\
\hline 2 & Campesterol & 17,46 & Antidiabetic $^{[17]}$ \\
\hline 3 & Palmitic Acid & 17,05 & Anticancer $^{[18]}$ \\
\hline 4 & Pyridine & 5,51 & Antidiabetic $^{[19]}$ \\
\hline 5 & Phytol & 1,87 & Antidiabetic $^{[20]}$ \\
\hline 6 & Cycloeucalenol & 1,13 & Antidiabetic $^{[21]}$ \\
\hline 7 & Tocopherol & 1,03 & Antioxidants $^{[22]}$ \\
\hline 8 & Pyranoisoflavones & 0,54 & Antidiabetic $^{[23]}$ \\
\hline 9 & Quinolone & 0,35 & Antibacterials ${ }^{[25]}$ \\
\hline 10 & Other & 35 & - $^{2}$ \\
\hline
\end{tabular}

Based on Table 3 above, we can conclude that bioactive compounds such as a steroid (campesterol), an alkaloid (pyridine), terpenoid (phytol and cycloeucalenol), tocopherol (vitamin E), and flavonoid (pyrano-isoflavones) have potential antidiabetic compounds. These bioactive compounds consistent with previous researches using mother-in-law's tongue leaves extracted using $70 \%$ ethanol such as campesterol by Vats et al. ${ }^{[17]}$, pyridine by Wang et al. ${ }^{[19]}$, phytol by Elmazar et al. ${ }^{[20]}$, cycloeucalenol by Ragasa et al. ${ }^{[21]}$, tocopherol by Monfalouti et al. ${ }^{[23]}$, and pyranoisoflavones by Nigel et al. ${ }^{[24]}$. It shows that, although $70 \%$ ethanol in-vitro extract has a weak $\mathrm{IC}_{50}$ value that is $4708.71 \mathrm{ppm}$ compared to positive control (acarbose) that has the $\mathrm{IC}_{50}$ value of $0.25 \mathrm{ppm}$, the extract still has the same bioactive compounds described by previous researchers.

\section{Conclusion}

Based on the results of the research, it can be concluded that the leaves of mother-in-law's tongue extract with $70 \%$ ethanol had the highest yield value, that is $12.69 \%$ and the percentage of inhibition $\alpha$-glucosidase was $90.72 \%$ at the inhibitor concentration of 4708.71 . This suggests that the extract with $70 \%$ ethanol has the required bioactive compound content as the $\alpha$-glucosidase enzyme inhibitor. Based on identification using the GCMS, compounds that have anti-diabetic activity is steroids, alkaloids, terpenoids, tocopherol, and flavonoid.
The authors gratefully acknowledge Universitas Indonesia for PITTA Research Grant 2018 and Department of Chemical Engineering for supporting this research.

\section{References}

1. WHO. Global Report on Diabetes, WHO. France: MEO Design \& Communication, meomeo.ch (2016)

2. Guntavid, J.P. Some Preliminary Observations of Sabah's Traditional Medicinal Plants. www.borneofocus.com (2001)

3. Hariana, A. Tumbuhan Obat dan Khasiatnya Seri 2. Jakarta: Penebar Swadaya (2008)

4. Lans, Cheryl A. Ethnomedicines Used in Trinidad and Tobago for Urinary Problems and Diabetes Mellitus, Journal of Ethnobiology and Ethnomedicine, 2, pp. 45 (2006)

5. Comerford, S.C. Medicinal Plants of Two Mayan Healers from San Andres, Peten, Guatemala, Economic Botany, 50(3), pp. 327-336 (1996)

6. Sunilson et al. Analgesic and Antipyretic Effects of Sansevieria trifasciata Leaves. Afr.J.Traditional, Complementary and Alternative Medicines 6 (4), pp. 529-533 (2009)

7. Lombogia B., Budiarso F., \& Bodhi W. Uji daya hambat ekstrak daun lidah mertua (Sansevieria trifasciata folium) terhadap pertumbuhan bakteri Escherichia coli dan Streptococcus sp. Jurnal eBiomedik (EBM), Volume 4, Nomor 1, JanuaryJuni. Medan: Fakultas Kedokteran, Universitas Sam Ratulangi Manado (2016)

8. Mahardika R. A. D., Hidayat N., \& Nurika I. Ekstraksi Antioksidan dari Lidah Mertua (Sansevieria trifasciata Prain) Menggunakan Metode Microwave-Assisted Extraction (MAE) dan Pulsed Electric Field. (2013)

9. Qomariyah, N. Antidiabetic Effects of a Decoction of Leaves of Sansevieria trifasciata in AlloxanInduced Diabetic White Rats (Rattus norvegicus L.). Bandung: LPPM ITB (2012)

10. Wijono, S. Isolasi dan identifikasi flavonoid pada daun katuk (Sauropus androgynus (L.) Merr). Makara Sains 7 (2), pp. 52-66 (2003).

11. Gamse T. Liquid-liquid Extraction and SolidLiquid Extraction. New York (US): Graz Pr (2002)

12. Suryani NC, Permana DGM, Jambe AAGNA. Pengaruh Jenis Pelarut terhadap Kandungan Total Flavonoid dan Aktivitas Antioksidan Ekstrak Daun Matoa (Pometia pinnata). Bali: Ilmu dan Teknologi Pangan, Fakultas Teknologi Pertanian, Universitas Udayana (2014)

13. Sancheti S, Seo SY. Chaenomeles sinensis: a potent $\alpha$-and $\beta$ - glucosidase inhibitor. American Journal of Pharmocology and Toxicology 4(1), pp. 8-11 (2009)

14. Yulianti. Uji Aktivitas Penghambatan Enzim $\alpha$ Glukosidase Ekstrak Metanol 80\% Daun Eceng Gondok (Eichhornia crassipes Solms.) Secara In Vitro. Jakarta: Fakultas Farmasi Universitas 17 Agustus 1945 (2014) 
15. Matthew, K.O., Olugbenga, O.S., Olajide, A.O. \& Doyin, A.F. The Effect of Bridelia ferruginea and Senna alata on Plasma Glucose Concentration in Normoglycemic and Glucose-Induced Hyperglycemic Rats, Ethnobotanical Leaflets. 10, pp. 209-218 (2006)

16. Peyrat-Maillard, M. N.; Cuvelier, M. E.; Berset, C. Antioxidant activity of phenolic compounds in 2,2'azobis (2-amidinopropane) dihydrochloride (AAPH)-induced oxidation: Synergistic and antagonistic effects. Journal of the American Oil Chemists' Society. 80 (10): 1007-1012. doi:10.1007/s11746-003-0812-z (2003)

17. Vats $\mathrm{S}$, Kamal R. In vivo and in vitro evaluation of sterols from Gymnema Sylvestre R. Br. Pak J Biol Sci 2013;16:1771-5 (2013)

18. Pascual, Gloria. Targeting metastasis-initiating cells through the fatty acid receptor CD36. Nature. doi:10.1038/nature20791 (2016)

19. Wang Z, Jiang H, Xia YG, Yang Y, Kuang HX. $\alpha$ Glucosidase inhibitory constituents from Acanthopanax senticocus harm leaves. Molecules 17:6269-6276. doi: 10.3390/molecules 17066269 (2012)

20. Elmazar, Mohamed M.; El-Abhar, Hanan S.; Schaalan, Mona F.; and Farag, Nahla A. Phytol/Phytanic acid, and insulin resistance: potential role of phytanic acid proven by docking simulation and modulation of biochemical alterations. World Biomedical Frontiers, ISSN: 2328-0166 (2013)

21. Ragasa, Consolacion Y.; Lim, Kosta Fremmielle; Shen, Chien-Chang; and Raga, Dennis D. Hypoglycemic Potential of Triterpenes from Alstonia scholaris. Pharmaceutical Chemistry Journal, Russian Original Vol. 47, No. 1 (2013)

22. Choe, Eunok; Min, David B. Mechanisms of Antioxidants in the Oxidation of Foods. Comprehensive Reviews in Food Science and Food Safety. 8(4), pp. 345-358. doi:10.1111/j.1541-4337.2009.00085.x (2009)

23. Monfalouti HE, Guillaume D, Denhez C, Charrouf Z. Therapeutic potential of argan oil: A review. J Pharm Pharmacol 2010;62:1669-75 (2010)

24. Nigel, $\mathrm{C}$ Veitch. Isoflavonoids of the Leguminosae. Nat. Prod. Rep, 2013, 30, 988 (RSC Publishing). doi:10.1039/c3np70024k (2013)

25. Aldred, Katie J.; Kerns, Robert J.; and Osheroff, Neil. Mechanism of Quinolone Action and Resistance. Biochemistry. 2014 Mar 18, 53 (10): 1565-1574. doi: 10.1021/bi5000564 (2014) 